\title{
Exploring the sensitivity of soil carbon dynamics to climate change, fire disturbance and permafrost thaw in a black spruce ecosystem
}

\author{
J. A. O'Donnell ${ }^{1}$, J. W. Harden ${ }^{2}$, A. D. McGuire ${ }^{3}$, and V. E. Romanovsky ${ }^{4}$ \\ ${ }^{1}$ University of Alaska Fairbanks, Biology \& Wildlife Department, Fairbanks, AK, USA \\ ${ }^{2}$ US Geological Survey, Menlo Park, CA, USA \\ ${ }^{3}$ US Geological Survey, Alaska Cooperative Fish and Wildlife Research Unit, University of Alaska, \\ Fairbanks, Fairbanks, AK, USA \\ ${ }^{4}$ University of Alaska Fairbanks, Geophysical Institute, Fairbanks, AK, USA
}

Received: 16 October 2010 - Published in Biogeosciences Discuss.: 6 December 2010

Revised: 4 May 2011 - Accepted: 14 May 2011 - Published: 27 May 2011

\begin{abstract}
In the boreal region, soil organic carbon (OC) dynamics are strongly governed by the interaction between wildfire and permafrost. Using a combination of field measurements, numerical modeling of soil thermal dynamics, and mass-balance modeling of OC dynamics, we tested the sensitivity of soil OC storage to a suite of individual climate factors (air temperature, soil moisture, and snow depth) and fire severity. We also conducted sensitivity analyses to explore the combined effects of fire-soil moisture interactions and snow seasonality on OC storage. OC losses were calculated as the difference in OC stocks after three fire cycles $(\sim 500 \mathrm{yr})$ following a prescribed step-change in climate and/or fire. Across single-factor scenarios, our findings indicate that warmer air temperatures resulted in the largest relative soil OC losses $\left(\sim 5.3 \mathrm{~kg} \mathrm{C} \mathrm{m}^{-2}\right)$, whereas dry soil conditions alone (in the absence of wildfire) resulted in the smallest carbon losses $\left(\sim 0.1 \mathrm{~kg} \mathrm{C} \mathrm{m}^{-2}\right)$. Increased fire severity resulted in carbon loss of $\sim 3.3 \mathrm{~kg} \mathrm{C} \mathrm{m}^{-2}$, whereas changes in snow depth resulted in smaller OC losses $\left(2.1-2.2 \mathrm{~kg} \mathrm{C} \mathrm{m}^{-2}\right)$. Across multiple climate factors, we observed larger OC losses than for single-factor scenarios. For instance, high fire severity regime associated with warmer and drier conditions resulted in OC losses of $\sim 6.1 \mathrm{~kg} \mathrm{C} \mathrm{m}^{-2}$, whereas a low fire severity regime associated with warmer and wetter conditions resulted in OC losses of $\sim 5.6 \mathrm{~kg} \mathrm{C} \mathrm{m}^{-2}$. A longer snow-free season associated with future warming resulted in $\mathrm{OC}$ losses of $\sim 5.4 \mathrm{~kg} \mathrm{C} \mathrm{m}^{-2}$. Soil climate was the dominant control on soil OC loss, governing the sensitivity of microbial decomposers to fluctuations in
\end{abstract}

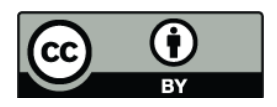

Correspondence to: J. A. O'Donnell (jodonnell@usgs.gov) temperature and soil moisture; this control, in turn, is governed by interannual changes in active layer depth. Transitional responses of the active layer depth to fire regimes also contributed to $\mathrm{OC}$ losses, primarily by determining the proportion of OC into frozen and unfrozen soil layers.

\section{Introduction}

High-latitude soils store large quantities of organic carbon (OC), accounting for nearly $50 \%$ of the global belowground OC pool (Tarnocai et al., 2009). Soil OC storage in many northern soils is governed by the presence of permafrost, which functions as a large reservoir for OC (Zimov et al., 2006). Recent warming at high latitudes has caused localized thawing of permafrost (Osterkamp and Romanovsky, 1999; Romanovsky et al., 2010), resulting in the release of old OC from terrestrial ecosystems (Schuur et al., 2009). Permafrost thaw also can alter local soil thermal and hydrologic conditions (Jorgenson et al., 2001; Yi et al., 2009b), which can influence rates of microbial activity and OC loss from decomposition. Modeling analyses project widespread thawing of permafrost in the next century (Euskirchen et al., 2006; Lawrence et al., 2008), but considerable uncertainty exists regarding the fate of soil OC following thaw (Limpens et al., 2008; Schuur et al., 2008).

Wildfire has the potential to exacerbate rates of permafrost thaw (Yoshikawa et al., 2003) and OC losses (Harden et al., 2000) from soils of the boreal region. Through the combustion of surface organic horizons, wildfire reduces thermal insulation and increases active layer depth (ALD; Burn, 1998; Yoshikawa et al., 2003; Johnstone et al., 2010).

Published by Copernicus Publications on behalf of the European Geosciences Union. 
Re-accumulation of the organic horizon between fire cycles can allow for the recovery of ALD to pre-fire depths (Yi et al., 2011). This interaction between wildfire and permafrost can have a profound influence on soil OC accumulation and loss (O'Donnell et al., 2011). ALD fluctuations across fire cycles determine the proportion of OC in unfrozen or frozen mineral soil, and thus, rates of OC accumulation or loss in deep soil horizons (O'Donnell et al., 2011). In this manner, ALD functions as a control on substrate (i.e. OC) availability to microbial decomposers in unfrozen soils. Furthermore, the magnitude of the ALD effect on soil OC loss is closely linked to fire regime characteristics, such as fire severity (O'Donnell et al., 2011).

Soil OC dynamics are also governed by the sensitivity of microbial decomposition to changes in soil climate, which in the boreal region, is governed by complex interactions among physical drivers, soil properties and disturbance (Jorgenson et al., 2010). For example, increased soil temperatures following fire can stimulate decomposition rates (Richter et al., 2000; O'Neill et al., 2002). However, the temperature sensitivity of decomposition may be reduced due to post-fire changes in soil moisture or OC quality (Neff et al., 2005; O'Donnell et al., 2009b). Wildfire can increase soil moisture content via reduced rates of evapotranspiration and interception (Moody and Martin, 2001), but can also decrease following fire (O'Neill et al., 2002). Similarly, permafrost thaw has caused both wetting and drying of terrestrial ecosystems, depending upon topographic position and ground ice content (Jorgenson et al., 2001; Jorgenson and Osterkamp, 2005). Increased snow depth can enhance soil warming and permafrost thaw (Nowinski et al., 2010), whereas decreases in snow-depth can promote rapid freezing during cooling periods (Goodrich, 1982; Stieglitz et al., 2003). The relative sensitivity of soil thermal conditions to these climatic drivers and disturbances will ultimately govern rates of decomposition, and in turn, will determine OC storage across the boreal landscape.

Here, we build on prior field and modeling studies (Harden et al., 2000; O'Donnell et al., 2011) to assess the relative sensitivity of soil OC storage to climate factors and fire disturbance in a black spruce ecosystem of interior Alaska. To achieve this objective, we used a combination of field measurements of soil temperature, moisture and snow dynamics, numerical modeling of soil thermal dynamics, and massbalance modeling of soil OC dynamics. Using this approach, we addressed the following questions. (1) What is the sensitivity of ALD and soil climate to air temperature, soil moisture, snow depth, and fire severity? (2) What is the sensitivity of soil OC storage to air temperature, soil moisture, snow depth, and fire severity? (3) What are the relative effects of ALD, soil climate, and ALD-soil climate interactions on soil OC losses across climate and fire scenarios? By addressing these questions, we aim to quantify the importance of individual climatic and disturbance factors governing soil OC dynamics in the boreal region.

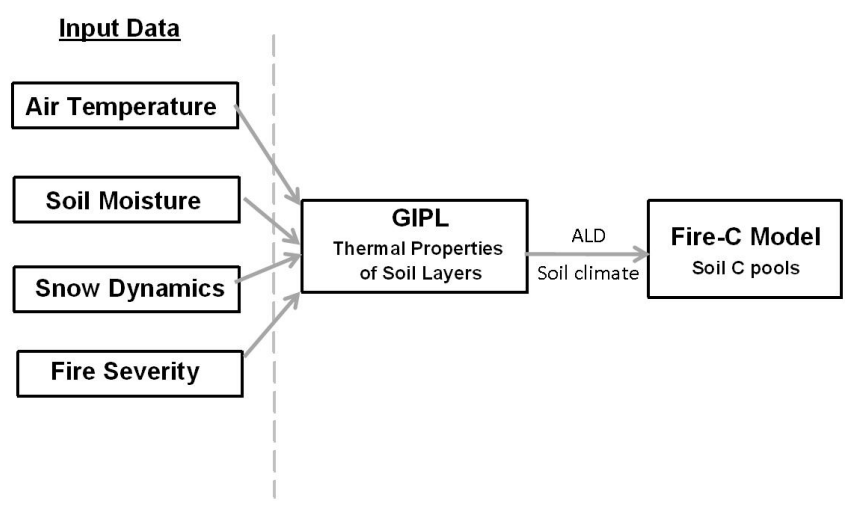

Fig. 1. The modeling framework of this study in which the Geophysical Institute Permafrost Laboratory (GIPL) model was calibrated from measured temperature input data. GIPL was then used to simulate active layer depth (ALD) and soil temperature profiles over a variety of climate and soil conditions. The Fire-C model used GIPL results to simulate changes in soil OC storage over multiple fire cycles based on ALD and soil temperature (August mean monthly temperature). Input data include air temperature, soil moisture, snow depth and fire severity (carbon fraction combusted during a fire event) from the Hess Creek study area collected from 20072009. Sensitivity analyses were conducted (see Table 1 for scenario details) using the GIPL model to assess the impact of input variables on ALD and soil temperatures. ALD and soil temperature data were then used to drive soil $\mathrm{C}$ turnover in the Fire-C model.

\section{Methods}

\subsection{Experimental design}

For this study, we combined field observations of temperature and soil moisture, numerical modeling, and massbalance modeling to quantify the relative effects of individual and combined climate/fire factors on net soil OC accumulation and loss (Fig. 1; Table 1). In this study, we modified the Fire-C model (Harden et al., 2000; O'Donnell et al., 2011) to improve simulations of ALD and OC dynamics in order to (1) account for deeper permafrost OC stocks, and (2) to incorporate in more detail the temperature and moisture controls on decomposition. In previous work, thermal conductivity of the organic horizon was measured across a range of moisture contents (O'Donnell et al., 2009a) and ALD was calculated as a function of organic horizon thickness across an upland fire chronosequence near Hess Creek, AK (see O'Donnell et al., 2011). For this study, we used the Geophysical Institute Permafrost Laboratory (GIPL) model (Romanovsky and Osterkamp, 1997; Nicolsky et al., 2007; Marchenko et al., 2008) to assess the sensitivity of ALD and soil temperature to a wide range of climatic factors (air temperature, moisture, snow, and fire severity) both as separate and combined. We then used output from these sensitivity analyses to assess the effects of ALD and soil climate on 
Table 1. Climate and disturbance scenarios tested using GIPL and Fire-C models.

\begin{tabular}{|c|c|c|}
\hline Climate/Disturbance Scenarios & Description & Source Data \\
\hline \multicolumn{3}{|l|}{ Air Temperature } \\
\hline A2 Scenario & $\begin{array}{l}\text { "Business as usual" scenario following IPCC } \\
\text { (Christensen et al., 2007) }\end{array}$ & Fig. 2 \\
\hline B1 Scenario & $\begin{array}{l}\text { Reduced greenhouse gas emission following IPCC } \\
\text { (Christensen et al., 2007) }\end{array}$ & Fig. 2 \\
\hline \multicolumn{3}{|l|}{ Soil Moisture } \\
\hline Wetter & $\begin{array}{l}25 \% \text { increase in VWC of organic soil horizons relative } \\
\text { to present-day values }\end{array}$ & Supplement Fig. S3 \\
\hline Drier & $\begin{array}{l}25 \% \text { decrease in VWC of organic soil horizons relative } \\
\text { to present-day values }\end{array}$ & Supplement Fig. S3 \\
\hline \multicolumn{3}{|l|}{ Snow Dynamics } \\
\hline Deeper Snowpack & $25 \%$ increase in snow depth relative to present-day values & Fig. 3 \\
\hline Shallower Snowpack & $25 \%$ decrease in snow depth relative to present-day values & Fig. 3 \\
\hline \multicolumn{3}{|l|}{ Fire Severity } \\
\hline Lower Severity & $25 \%$ of organic horizon combusted during fire & Harden et al. (2000) \\
\hline Higher Severity & $77 \%$ of organic horizon combusted during fire & Kane et al. (2007) \\
\hline \multicolumn{3}{|l|}{ Multiple Factors } \\
\hline High Severity $\times$ Drying $\times$ Warming & Interactive effects of high severity fires ( $77 \%)$, warming (A2), and drying & \\
\hline Low Severity $\times$ Wetting $\times$ Warming & Interactive effects of low severity fires ( $25 \%)$, warming (A2), and wetting & \\
\hline Longer Snow-free Season & $\begin{array}{l}\text { Snowmelt } 21 \text { days earlier, snow return } 20 \text { days later than present day } \\
\text { (Euskirchen et al., 2009) }\end{array}$ & Fig. 3 \\
\hline
\end{tabular}

organic matter decomposition and soil OC accumulation using a simple mass-balance, long-term model (O'Donnell et al., 2011).

\subsection{Modeling soil carbon dynamics}

The soil OC dynamics model used in this study was originally developed by Harden et al. (2000) to track long-term trends in soil carbon inventories of shallow and deep organic horizons across fire cycles. This model was subsequently modified to include inputs from coarse woody debris (Manies et al., 2005) and to include OC dynamics in mineral soil of the active layer and near-surface permafrost (O'Donnell et al., 2011). Briefly, the model uses a mass-balance approach to examine net changes in soil OC storage over time $(d \mathrm{C} / d t)$ as governed by OC inputs (net primary production (NPP) from moss and trees) and losses (heterotrophic respiration and fire). OC inputs are prescribed as the average NPP over a fire cycle (or $\sim 150 \mathrm{yr}$ ). At present, the model does not account for dissolved carbon losses. All model simulations were run using Microsoft Excel (Microsoft Corporation, Redmond, WA, USA). Here we discuss further improvements and modifications to the model, which include GIPL-modeled active layer dynamics, and temperature and moisture regulation of decomposition.

\subsubsection{Active layer dynamics}

In the modeling study by O'Donnell et al. (2011), active layer depth was calculated simply as a function of organic horizon thickness at time $t$ (in years) for the study area near Hess Creek. To more precisely represent active layer dynamics in the model, we reconstructed active layer depth vs. organic horizon thickness regression curves across a range of climate conditions using the GIPL model (as discussed in Sect. 2.4 below). The equations derived from these relationships were then used as a control on soil OC dynamics in the Fire-C model across different climatic scenarios.

\subsubsection{Deep soil carbon}

In a prior version of the model, we tracked soil $\mathrm{C}$ inventories between the ground surface and a depth of one meter (O'Donnell et al., 2011). Here, we have parameterized the model to track soil OC inventories in the top two meters. In most mature forests in Alaska, soil OC between one and two meters resides in the permafrost pool (Tarnocai et al., 2009). However, post-fire thawing of near-surface permafrost can result in thaw depths exceeding one meter (e.g. Viereck et al., 2008), which might impact deeper OC stocks ( $>$ one meter). 


\subsubsection{Temperature and moisture controls on decomposition}

In a prior version of the model (O'Donnell et al., 2011), decomposition constants $(k)$ were derived using chronosequence and radiocarbon methodologies. In that study, $k$ reflected the apparent decomposability of soil organic matter (see Davidson and Janssens, 2006), integrating the effects of temperature, soil moisture and organic matter quality on decomposition during historic times. However, future climate scenarios require that $k$ respond to fluctuations in soil temperature and moisture.

We used the following equation to calculate an inherent $k$, which integrates the decomposability of a substrate based on its molecular structure at ambient temperature:

$k=\frac{k_{\text {base }}}{e^{r T} f(\vartheta)}$

where $k$ is the inherent decomposition constant, $k_{\text {base }}$ is the apparent decomposition constant as reported in O'Donnell et al. (2011), $r$ is a parameter describing the temperature sensitivity of decomposition, $T$ is the mean monthly soil temperature for the month of August (as measured or calculated across the fire chronosequence), when maximum thaw depth occurs during the year, and $f(\theta)$ is a soil moisture scalar that relates the relative rate heterotrophic respiration to gravimetric soil moisture content. We used GIPL output to prescribe $T$ for each soil horizon, with soil depths of $5,15,45$, and $200 \mathrm{~cm}$ representing shallow organic, deep organic, unfrozen mineral soil of the active layer, and perennially frozen soil horizons, respectively. The function $f(\theta)$ is a value between 0 and 1 , with optimal decomposition occurring when $f(\theta)$ is around 0.6, and was calculated following the equations of Frolking et al. (1996) for a feather moss-dominated black spruce forest. To determine a value for $r$, we used a temperature sensitivity quotient $\left(Q_{10}\right)$ equation:

$r=\frac{\ln \left(Q_{10}\right)}{10}$

We used a different $Q_{10}$ value for each soil layer, as reported in the literature. For shallow organic horizons, we prescribed a $Q_{10}$ of 1.9, as reported by Wickland and Neff (2007) for fibric organic matter. For deep organic horizons (i.e. mesic or humic horizons), we prescribed a $Q_{10}$ value of 4.4 , as reported by Dioumaeva et al. (2003). For unfrozen mineral soil of the active layer, we prescribed a $Q_{10}$ of 2.0, as reported in other studies (Clein and Schimel, 1995; Frolking et al., 1996; Carrasco et al., 2006). For near-surface permafrost, we lowered the $Q_{10}$ value of unfrozen mineral soil to $30 \%$ of its value, following the work of Dioumaeva et al. (2003) and Fan et al. (2008), to account for reduced microbial activity at temperatures below freezing. We then used soil temperature output from the GIPL model (see Sect. 2.4 for details) to calculate $T$ across all climate and fire sensitivity analyses (Fig. 1). $f(\theta)$ was only re-calculated for the two climate scenarios in which we prescribed wetter or drier conditions.

\subsection{Field measurements of soil temperature, moisture and snow depth}

Soil thermal and snow dynamics were monitored at sites along the Hess Creek fire chronosequence $\left(\mathrm{N} 65.56700^{\circ}\right.$, W148.92400, approximately $150 \mathrm{~km}$ north of Fairbanks) of O'Donnell et al. (2011). All study sites were located on north-facing slopes underlain by permafrost and were somewhat poorly drained, and generally representative of black spruce ecosystems in the discontinuous permafrost zone of Alaska (e.g. Kane et al., 2005) and Canada (Harden et al., 1997). The regional climate of interior Alaska is strongly continental, with very cold winters and warm, relatively dry summers. At the Hess Creek study region, the average daily air temperature ranges from $-25^{\circ} \mathrm{C}$ in January to $15^{\circ} \mathrm{C}$ in July. Annual precipitation averages $270 \mathrm{~mm}, 65 \%$ of which falls during the short summer growing season (early-May to mid-September).

In mature black spruce (Picea mariana (Mill.) B.S.P.) stands, the forest understory was composed of small woody shrubs, such as Vaccinium vitis-idaea and Ledum groenlandicum. Feather mosses (Pleurozium schreberi and Hylocomium splendens), Sphagnum (S. fuscum) and reindeer lichens (Cladina stellaris and C. arbuscula) dominated ground cover in the mature black spruce stands. In the recently burned black spruce stands (2003 Erickson Creek fire), vegetation was dominated by standing dead P. mariana, and living V. vitis-idaea, V. uliginosum, L. groenlandicum, and Equisetum spp. Burned organic soil surfaces were quickly colonized by Ceratodon purpureus in the recently burned stands. In the stands that burned in 1967, P. mariana and $B$. neoalaskana were the dominant tree species, $V$. vitisidaea and $L$. groenlandicum were the dominant understory shrubs, and the feather moss $H$. splendens dominated ground cover.

We measured soil temperature, soil moisture, and ALD and snow depth at three stand ages (Unburned Mature, 2003 Burn, 1967 Burn). These different stand ages provide a natural gradient in soil properties such as organic horizon thickness, soil thermal dynamics, ALD, and soil OC stocks (O'Donnell et al., 2011). From September 2007 to September 2009, we monitored soil temperature every two hours using HOBO Pro V2 two-channel dataloggers (Onset Computer Corporation, Pocasset, MA, USA). We also used HOBO Smart Temperature sensors to monitor temperature at a single depth at each site. Temperature probes were installed at the ground surface, at the top of the permafrost (i.e. TTOP), near two meters below the ground surface, and also at the interface of key organic soil horizons. Soil moisture of organic soil horizons was also logged every two hours at each stand age using $\mathrm{ECH}_{2} \mathrm{O}$ Smart Soil Moisture probes routed to a HOBO microstation (Onset Computer Corporation, Pocasset, MA, USA). Soil moisture probes were installed within distinct organic soil horizons. In addition to temperature and soil moisture, we conducted snow surveys 
Table 2. Organic horizon thicknesses and active layer depths across upland fire chronosequence.

\begin{tabular}{lcccrrl}
\hline Site & $\begin{array}{r}\text { Live/Dead } \\
\text { Moss }(\mathrm{cm})\end{array}$ & $\begin{array}{r}\text { Fibric } \\
(\mathrm{cm})\end{array}$ & $\begin{array}{r}\text { Mesic/Humic } \\
(\mathrm{cm})\end{array}$ & $\begin{array}{r}\text { Organic Horizon } \\
(\mathrm{cm})\end{array}$ & $\begin{array}{l}\text { Active Layer } \\
\text { Depth }(\mathrm{cm})\end{array}$ \\
\hline Unburned Mature & 33 & $6 \pm 2$ & $8 \pm 4$ & $10 \pm 6$ & $24 \pm 5$ & $45 \pm 8$ \\
2003 Burn & 23 & $3 \pm 4$ & $5 \pm 4$ & $6 \pm 3$ & $14 \pm 5$ & $66 \pm 12$ \\
1990 Burn & 10 & $4 \pm 3$ & $4 \pm 5$ & $2 \pm 3$ & $9 \pm 4$ & $77 \pm 19$ \\
1967 Burn & 11 & $4 \pm 2$ & $4 \pm 3$ & $6 \pm 2$ & $15 \pm 4$ & $54 \pm 7$ \\
\hline
\end{tabular}

Note: values represent mean \pm one standard error.

over two winters. At each stand age, we measured snow depth every $6 \mathrm{~m}$ across a $30 \mathrm{~m}$ linear transect on 13 November, 25 February, and 3 April 2007 and 2008 and we also measured snow depth on 2 April 2009.

\subsection{Modeling soil temperature dynamics}

We used the GIPL model to simulate the depth of seasonal freezing and thawing by solving a one-dimensional non-linear heat equation with phase change (Nicolsky et al., 2007). To calibrate the GIPL thermal model for the Hess Creek study sites, we combined field measurements of soil temperature (Supplement Figs. S1 and S2), soil moisture (Supplement Fig. S3), ALD, snow depth, field descriptions of soil horizon thickness (O'Donnell et al., 2011), and empirical calculations of thermal conductivity (O'Donnell et al., 2009a). For each study site (Unburned Mature, 2003 Burn, 1967 Burn), the measured soil temperature data were used to calibrate the model, which in turn was used to reconstruct the one-dimensional temperature field in the active layer and near-surface permafrost. We used air temperature and snow depth measurements from Hess Creek to drive model simulations of soil temperature. For soil parameterizations, we divided the organic horizon into three layers: live/dead moss, fibrous organic matter, and amorphous organic matter (Table 2), following the approach of Yi et al. (2009a). Mineral soil horizons were divided into active layer soil, frozen loess, and frozen bedrock. We prescribed soil moisture content for organic horizons based on mean volumetric water content (VWC) measured during the summer of 2008 (Table 3; Supplement Fig. S3). Unfrozen thermal conductivity values for organic horizons were calculated from measured VWC values (O'Donnell et al., 2009a; Table 3). Frozen thermal conductivity, volumetric heat capacity, and volumetric unfrozen water content parameters were prescribed following previous studies (Romanovsky and Osterkamp, 1997, 2000).

Following model calibration, we used the GIPL model to determine the sensitivity of ALD and soil temperatures to changes in air temperature, snow dynamics, soil moisture, and fire severity (Fig. 1; Table 1). For all sensitivity analyses, we introduced a step-change in climate or fire disturbance in order to evaluate effects at the year 2100 relative to the present day. The step-change approach allowed us to compare the relative sensitivity of ALD and soil temperature to climate factors and fire disturbance, and in turn, explore the underlying mechanisms of soil OC loss in the boreal region. Given this approach, our analyses were not intended to provide an exact projection of future permafrost thaw. For a more precise estimation of ALD and soil temperature responses to future climate and fire, a transient simulation from the present day to 2100 (e.g. Lawrence et al., 2008) would be more appropriate than the step-change method.

To assess the effect of atmospheric warming, we increased mean daily air temperature (as measured at Hess Creek) to match predicted air temperatures under the A2 (business as usual) and B1 (reduced greenhouse gas emissions) warming scenarios (Christensen et al., 2007). To assess the effects of future wetting or drying scenarios on active layer depth, we increased and decreased soil moisture content of organic horizons by $25 \%$ relative to present-day measurements (Supplement Fig. S3), with concomitant changes in thermal conductivity following O'Donnell et al. (2009a). We also ran two alternate snow scenarios where daily snow depth was increased by $25 \%$ and decreased by $25 \%$ relative to presentday measurements. To assess the sensitivity of ALD and soil temperatures to fire severity, we first prescribed a moderate fire severity (64\% of organic matter combusted) and high fire severity (77\% of organic matter combusted, following Kane et al., 2007) relative to present-day fire severity (41\% of organic matter combusted; Harden et al., 2006).

We also ran scenarios to test the combined effects of climate and fire severity. For instance, we ran two scenarios to test the interactive effects of fire severity (high, low), moisture (wet, dry) and warming (A2 scenario; Table 1) relative to the present day. We also ran a scenario to reflect changes in snow seasonality associated with future warming. Following estimates of temporal snow dynamics by Euskirchen et al. (2009), our simulations reflected snow conditions at the year 2100, with snowmelt occurring 21 days earlier in the spring and snow return occurring 20 days later in the fall as compared present-day conditions. The A2 warming scenario was also used as driving data for the changing snow seasonality treatment. 
Table 3. GIPL model parameterizations at three study sites across fire chronosequence at Hess Creek, AK.

\begin{tabular}{|c|c|c|c|c|}
\hline Site & $\begin{array}{l}\text { Horizon thickness }{ }^{\mathrm{a}} \\
\qquad(\mathrm{cm})\end{array}$ & $\begin{array}{l}\text { Volumetric water content }{ }^{\mathrm{b}} \\
\qquad \%)\end{array}$ & $\begin{array}{l}\text { Unfrozen thermal conductivity } \\
\qquad\left(\mathrm{W} \mathrm{m}^{-1} \mathrm{~K}^{-1}\right)\end{array}$ & $\begin{array}{l}\text { Frozen thermal conductivity } \\
\qquad\left(\mathrm{W} \mathrm{m}^{-1} \mathrm{~K}^{-1}\right)\end{array}$ \\
\hline \multicolumn{5}{|l|}{ Unburned Mature } \\
\hline live/dead moss & 5 & 20 & 0.07 & 0.15 \\
\hline fibric & 11 & 25 & 0.15 & 0.20 \\
\hline mesic/humic & 8 & 30 & 1.40 & 2.00 \\
\hline \multicolumn{5}{|l|}{2003 Burn } \\
\hline fibric & 8 & 49 & 0.26 & 0.75 \\
\hline mesic/humic & 5 & 55 & 0.25 & 0.75 \\
\hline \multicolumn{5}{|l|}{1967 Burn } \\
\hline live/dead moss & 6 & 20 & 0.25 & 1.20 \\
\hline fibric & 5 & 25 & 0.25 & 1.50 \\
\hline mesic/humic & 9 & 68 & 0.40 & 1.40 \\
\hline
\end{tabular}

Note: parameterizations for specific heat capacity and unfrozen water content for each horizon were taken from calibration conducted by Romanovsky and Osterkamp (2000).

${ }^{a}$ Horizon thickness reflect average measurements for each horizon type as measured across the Hess Creek chronosequence (O'Donnell et al., 2010).

b VWC values vary with one standard deviation of the summer mean VWC, as measured in this study (Supplement Fig. S3). VWC data calibrated following O'Donnell et al. (2009a).

c Unfrozen thermal conductivity values were calculated from the VWC measurements following the equations by O'Donnell et al. (2009b).

${ }^{\mathrm{d}}$ Frozen thermal conductivity values were prescribed following Romanovsky and Osterkamp (2000).

\subsection{Sensitivity of soil carbon to future climate and fire scenarios}

To assess the sensitivity of soil OC to future climate and fire scenarios, we coupled the GIPL model with the Fire-C model (Fig. 1). As described in Sect. 2.4, the GIPL model was used to estimate ALD and soil climate (i.e. soil temperature profiles) under different air temperature, soil moisture, snow depth, and fire severity scenarios (Table 1). The ALD and soil climate output from GIPL was then used to drive soil OC dynamics in the Fire-C model (Fig. 1). We ran the Fire-C model at annual time-step for a total of $7000 \mathrm{yr}$. For the first $6500 \mathrm{yr}$, we ran the model spin-up to simulate historic climate conditions and fire regimes, following the same parameterizations as O'Donnell et al. (2011). Model verification by O'Donnell et al. (2011) demonstrated good agreement between present-day OC stocks and simulated OC stocks at the end of the spin-up. At model year 6500, we modified Fire-C parameters to reflect future climate conditions and fire regimes (Table 1). More specifically, we used output from GIPL scenarios to prescribe differences in ALD (Sect. 2.2.1) and/or soil climate controls on decomposition (Sect. 2.2.3). Using this coupled-model approach, we then tested the sensitivity of soil OC to air temperature (A2 vs. B1 scenarios), soil moisture (wetter vs. drier), snow depth (deeper vs. shallower), and fire severity (low severity, or $25 \%$ vs. high severity, or $77 \%$ ). We also tested the sensitivity of soil OC to the combined climate and fire effects. Specifically, we evaluated the effects of increased fire severity associated with drier and warmer condition, decreased fire severity with wetter and warmer conditions, and changes in snow seasonality associated with future warming. The net change in OC storage for each scenario was calculated as the difference between total OC stocks (top two meters) at 6500 (i.e. present day) and 7000 yr (i.e. after 3 fire cycles).

All model simulations using the Fire-C model were run to assess the magnitude of both ALD and soil climate effects on soil OC dynamics. To isolate the "ALD effect" on soil $\mathrm{OC}$, we first ran the Fire- $\mathrm{C}$ model by only changing the relationship between ALD and organic horizon thickness, as simulated by the GIPL model. To isolate the "soil climate effect" on soil OC dynamics, we then ran the Fire-C model by only changing the soil temperature (as simulated by GIPL) and moisture controls on decomposition rates. To assess the combined "ALD + soil climate" effect on soil OC dynamics, we ran the Fire-C model a third time changing both ALD dynamics and soil climate controls on decomposition rates. For each effect (ALD, soil climate, ALD + soil climate), we calculated the net effect on soil OC accumulation or loss.

\section{Results}

\subsection{Thermal model calibration}

Field measurements of air temperature and snow depth were used to calibrate the GIPL model. Air temperature varied seasonally with maxima occurring during July (monthly mean $=14.9^{\circ} \mathrm{C}$ ) and minima during January (monthly mean $=-25.3^{\circ} \mathrm{C}$ ). Snow depth varied across survey dates but not among study sites across the fire chronosequence (Fig. 2a). Minimum snow depths were measured in November, ranging between 7 and $9 \mathrm{~cm}$ across study sites. Maximum snow depths were measured in April and varied between years. In winter 2007-2008, maximum snow depths 

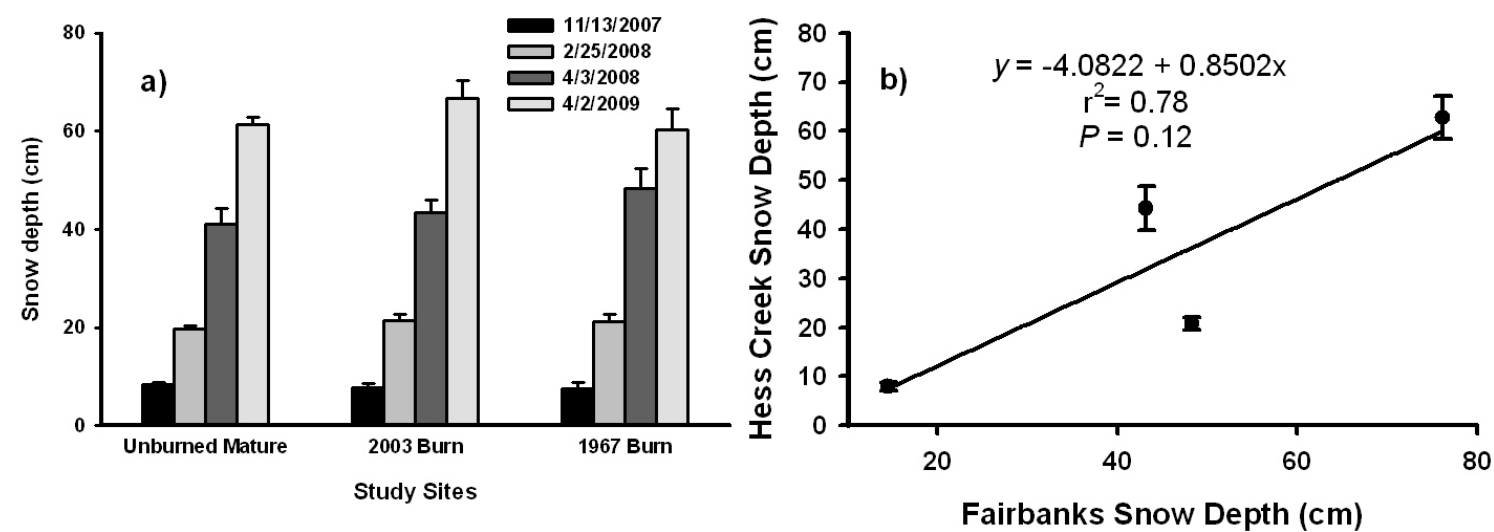

Fig. 2. (a) Results from snow surveys conducted the winter of 2007-2008 and April 2009 at the Hess Creek study sites. (b) Linear curve fit between snow depth measured at Hess Creek and near Fairbanks (data from Bonanza Creek Long-Term Ecological Research Station, www.lter.uaf.edu).

averaged between 41 and $48 \mathrm{~cm}$, whereas in winter 2008 2009, maximum snow depths averaged between 60 and $67 \mathrm{~cm}$. We observed a marginally good, but non-significant relationship between snow depths at Hess Creek and at a long-term monitoring site near Fairbanks, AK (Fig. 2b), described by the equation: $y=-4.0822+0.8502 x\left(R^{2}=0.78\right.$; $P=0.12$ ). We used this relationship to calculate daily snow depth at Hess Creek during model calibration.

We observed good agreement between measured and modeled soil temperatures (Fig. 3) and ALD (Supplement Fig. S4) at sites across the Hess Creek fire chronosequence. At the ground surface, modeled mean daily temperature (MDT) closely tracked observed MDT during winter, summer and during seasonal transitions (e.g. snowmelt). Deeper in the soil profile, we observed small differences $\left(<0.5^{\circ} \mathrm{C}\right)$ during winter and summer between modeled and observed ground temperatures (Fig. 3b-d). The differences were most pronounced during periods of cooling in the fall/early winter and warming during spring/early summer. The differences in ground temperature during periods of cooling have been attributed to the influence of unfrozen water content (Romanovsky and Osterkamp, 1997, 2000). During periods of warming in spring, ground temperatures were likely influenced by infiltration and re-freezing of snowmelt waters. These processes typically result in the formation of a "zero-degree curtain" at the ground surface, which we observed at our study sites during spring. Following the completion of snowmelt, thawing of the active layer began with ground temperatures $>0{ }^{\circ} \mathrm{C}$. Modeled ALD was within $3 \mathrm{~cm}$ of the observed ALD across the three study sites (Supplement Fig. S4).

\subsection{Modeling the sensitivity of active layer depth and soil climate to climate and fire}

Warmer air temperatures alone had a large impact on ALD (Fig. 4a; Table 4), with the A2 scenario increasing ALD by an average of $37 \pm 3 \mathrm{~cm}$ relative to present-day air temperatures across a range of organic horizon thicknesses. The B1 scenario resulted in considerably smaller increases in ALD, averaging $9 \pm 1 \mathrm{~cm}$ across a range of organic horizon thicknesses. Changes in soil moisture had a moderate influence on ALD (Fig. 4b), with wetter conditions driving an average ALD increase of $5.4 \pm 0.7 \mathrm{~cm}$ and drier conditions driving an average ALD decrease of $7.0 \pm 1.2 \mathrm{~cm}$ across a range of organic horizon thicknesses. Snow depth had a very small impact on ALD, with average ALD increasing or decreasing by $2 \pm 0 \mathrm{~cm}$ with deeper or shallow snowpack, respectively (Fig. 4c). High fire severity caused an average increase in ALD of $18 \pm 5 \mathrm{~cm}$, whereas low fire severity caused an average decrease in ALD of $7 \pm 1 \mathrm{~cm}$ (Fig. 4d).

In addition to driving changes in ALD, individual climate and fire factors caused changes in soil temperature in the active layer and near-surface permafrost (Fig. 5). Warming associated with the A2 scenario increased soil temperature by $3.5-4.5^{\circ} \mathrm{C}$ for August MMT in active layer soils. The B1 scenario resulted in higher soil temperatures by 0.7 to $1.0^{\circ} \mathrm{C}$ relative to present-day climate conditions. Soil moisture also had a moderate influence on August MMT in the active layer, as wetter conditions resulted in an increase of $0.3-0.6^{\circ} \mathrm{C}$ and drier conditions resulted in decrease of up to $0.5^{\circ} \mathrm{C}$ relative to present-day conditions. Deeper snowpack resulted in slight increases and shallower snowpack resulted in slight decreases in August MMT relative to present-day conditions. Increased fire severity (as prescribed through changes in organic horizon thickness) increased August MMT by 0.4 to $1.5^{\circ} \mathrm{C}$, whereas decreased fire severity cooled August MMT by up to $0.3^{\circ} \mathrm{C}$ relative to present-day conditions. 

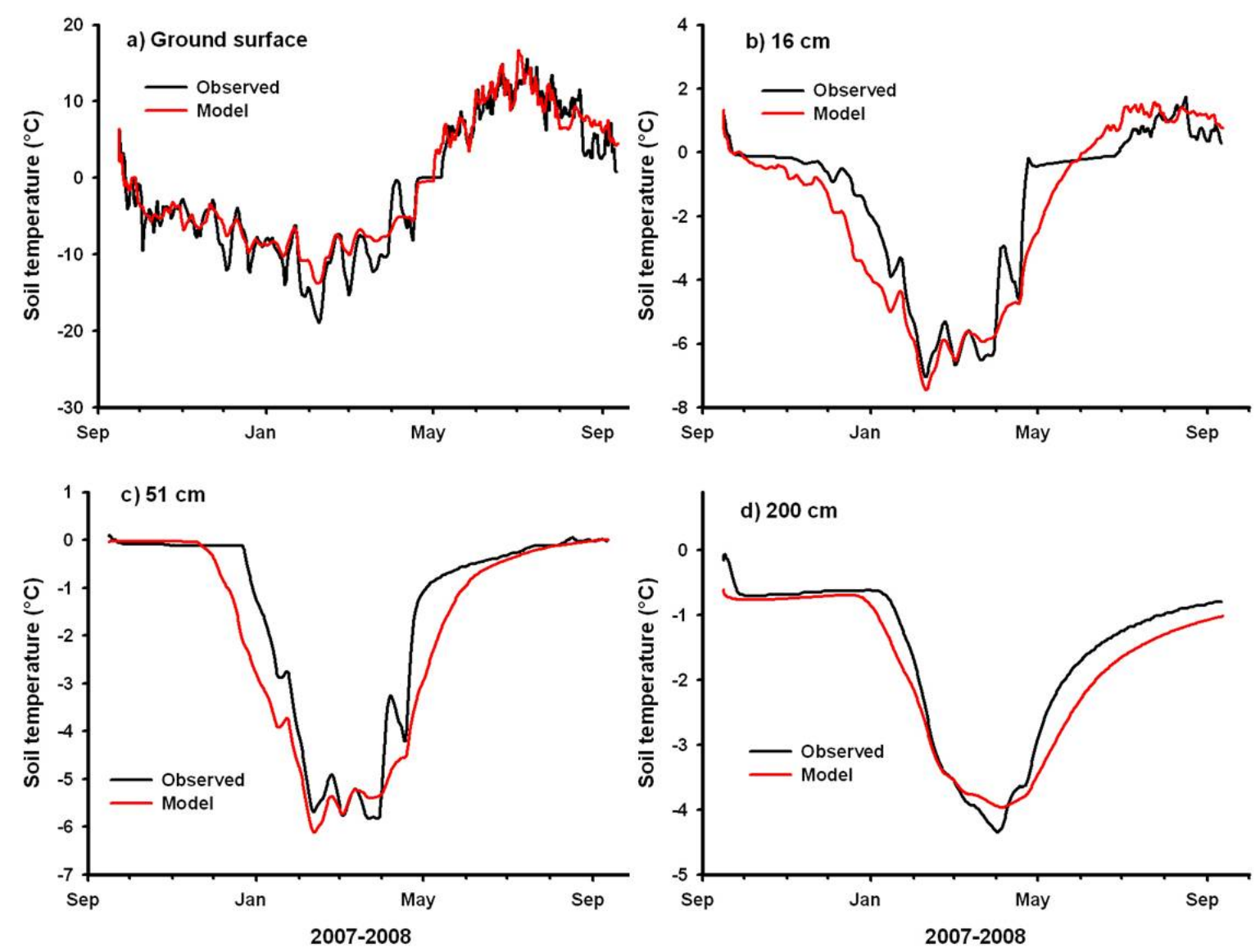

Fig. 3. Comparison of model soil temperature outputs (from GIPL2) and observed soil temperatures at different depths at the unburned mature site near Hess Creek. Model was separately parameterized for 2003 Burn and 1967 Burn soil profiles.

When considered as combined effects, we found that high fire severity, drier soils and warmer air temperatures resulted in the largest increase in ALD (mean $=56 \pm 6 \mathrm{~cm}$; Fig. 6a; Table 4) and August MMT $\left(4.7-5.5^{\circ} \mathrm{C}\right.$ increase in active layer soils; Fig. 6b). The combined effects of low severity fires, wetter soils and warmer air temperatures resulted in more modest increases in ALD (mean $=37 \pm 4 \mathrm{~cm}$ ) and August $\left(3.6-5.0^{\circ} \mathrm{C}\right.$ increase in active layer soils). Longer snow-free seasons associated with future warming also resulted in large increases in ALD (mean $=39 \pm 3 \mathrm{~cm}$ ) and August MMT $\left(3.6-4.6^{\circ} \mathrm{C}\right.$ increase in active layer soils).

\subsection{Modeling the sensitivity of soil carbon to climate and fire}

Of the individual climate factors, the A2 warming scenario (no change in fire severity) resulted in the largest OC losses from soil (5.3 $\mathrm{kg} \mathrm{C} \mathrm{m}^{-2}$; Fig. 7), whereas the drier soil moisture scenario in the smallest losses $\left(0.06 \mathrm{~kg} \mathrm{C} \mathrm{m}^{-2}\right)$. After the A2 scenario, the high fire severity treatment resulted in the next largest $\mathrm{OC}$ losses $\left(3.3 \mathrm{~kg} \mathrm{C} \mathrm{m}^{-2}\right)$. Changes in snow depth and increases in soil moisture resulted in minimal OC losses, ranging from $2.1-2.2 \mathrm{~kg} \mathrm{C} \mathrm{m}^{-2}$. When the model was run for three fire cycles under the present-day climate (with no changes in snow, moisture or fire), we also observed an OC loss of $2.1 \mathrm{~kg} \mathrm{C} \mathrm{m}^{-2}$. Across individual climate scenarios, interannual changes in ALD (i.e. the ALD effect) accounted for $61 \%$ of the total OC losses, whereas changes in soil temperature and/or moisture (i.e. the soil climate effect) accounted for $82 \%$ of total OC losses.

When multiple climate factors were considered as combined effects, we generally observed larger OC losses from soil relative to the individual factor analyses (Fig. 8). The high fire severity scenario associated with drier soil and warmer air temperature resulted in a soil OC loss of $6.1 \mathrm{~kg} \mathrm{C} \mathrm{m}^{-2}$. The low fire severity scenario associated with wetter soil and warmer air temperature resulted in a soil OC loss of $5.6 \mathrm{~kg} \mathrm{C} \mathrm{m}^{-2}$. The scenario reflecting longer snowfree season and warmer air temperatures resulted in a soil OC loss of $5.4 \mathrm{~kg} \mathrm{C} \mathrm{m}^{-2}$. Across combined-effect scenarios, the ALD effect accounted for $39 \%$ of total OC losses, while the soil climate effect accounted for $79 \%$ of total OC losses. 

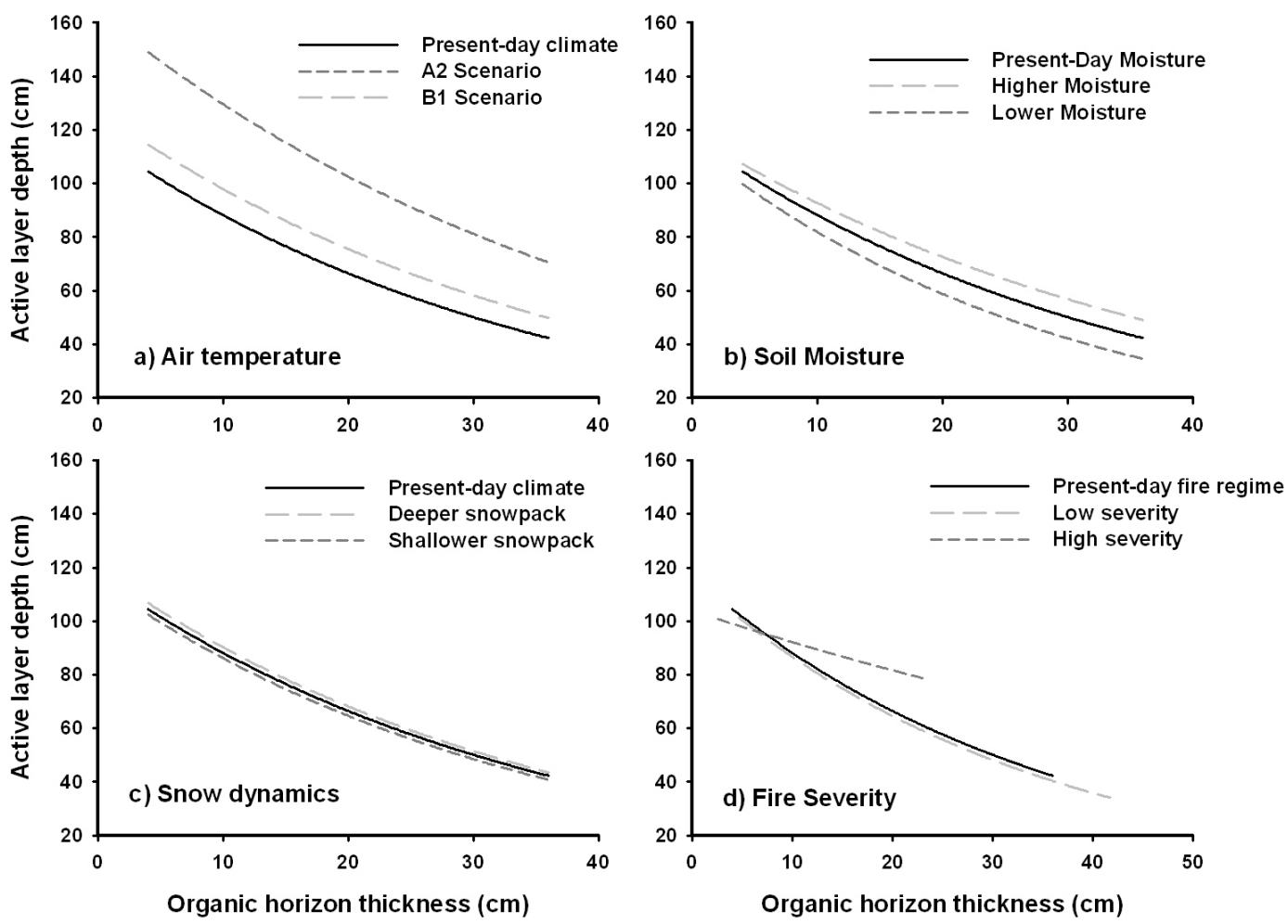

Fig. 4. Sensitivity of the active layer depth (ALD) to temperature, soil moisture, snow dynamics and fire severity. The relationship between ALD and organic horizon thickness was modeled using GIPL across a range of future air temperatures (a; IPCC scenarios), moisture conditions (b), snow (c), and fire severity (d). Output data from each scenario were then fit with the exponential equation: ALD $=a$. $e^{-b \cdot \mathrm{OHT}}$, where OHT is organic horizon thickness, and are summarized in Table 4. Equations were then used to run Fire-C model to evaluate sensitivity of soil carbon to various climate scenarios.

\section{Discussion}

\subsection{Effects of air temperature on active layer depth, soil climate and soil carbon}

Terrestrial ecosystems have the potential to act as a positive feedback to the climate system in response to warmer air temperatures (e.g. Friedlingstein et al., 2006), given the temperature sensitivity of heterotrophic respiration and subsequent $\mathrm{CO}_{2}$ release from soils. In this study, we illustrate the importance of higher air temperatures for OC loss from boreal soil. When compared to other individual factors (soil moisture, snow depth, fire severity), higher air temperatures caused the largest OC losses from soil in an upland black spruce ecosystem. Through our modeling analyses, we were able to isolate two potential mechanisms underlying OC losses. First, higher air temperatures resulted in warmer soil temperatures, which stimulated microbial decomposition of soil organic matter following $Q_{10}$ value for each soil horizon. Second, higher air temperatures, and in particular the A2 warming scenario, resulted in large increases in active layer depth (ALD), which transferred considerable amounts of OC from the permafrost to a thawed C pool (e.g. Schuur et al., 2008), where decomposition rates were higher (Mikan et al., 2002). Above $0{ }^{\circ} \mathrm{C}$, decomposition rates are typically described by an exponential relationship with temperature (Lloyd and Taylor, 1994; Kirschbaum, 2000), whereas decomposition rates below $0{ }^{\circ} \mathrm{C}$ are indirectly related to temperature, constrained by the availability of unfrozen water (Rivkina et al., 2000; Romanovsky and Osterkamp, 2000). Explicit consideration of freeze-thaw fronts (e.g. Yi et al., $2009 \mathrm{~b}$ ) and phase change effects on soil OC dynamics in ecosystem models will help in reducing these uncertainties. Furthermore, increased heterotrophic respiration associated with warming will likely be accompanied by increased nitrogen availability and plant production (Mack et al., 2004), although the net $\mathrm{C}$ balance is likely to favor an increase of $\mathrm{CO}_{2}$ relative to pre-disturbance conditions (Bond-Lamberty et al., 2007).

The temperature sensitivity of organic matter decomposition and soil respiration remains a critical uncertainty in predicting soil OC release to the atmosphere under future warming scenarios (Davidson and Janssens, 2006; Kirschbaum, 2006; Heimann and Reichstein, 2008). In the present modeling study, we prescribed horizon-specific $Q_{10}$ values for decomposition in four soil layers based on previously 
Table 4. Parameters and statistics for exponential equation $\left(f=a e^{-b x}\right)$ relating active layer depth (ALD) and organic horizon thickness across climate and fire scenarios.

\begin{tabular}{llllr}
\hline & \multicolumn{4}{c}{ ALD $\times$ Organic Horizon Thickness } \\
\cline { 2 - 5 } Climate/Disturbance Scenario & $a$ & $b$ & $R^{2}$ & $P$ \\
\hline $\begin{array}{l}\text { Present-Day Climate } \\
\quad 2007-2009\end{array}$ & 116.9490 & 0.0282 & 0.93 & $<0.0001$ \\
\hline Air Temperature & & & & \\
$\quad$ A2 Scenario & 163.6927 & 0.0234 & 0.85 & 0.0010 \\
B1 Scenario & 127.0604 & 0.026 & 0.89 & 0.0004 \\
\hline Soil Moisture & & & & \\
$\quad$ Wetter & 118.3910 & 0.0245 & 0.92 & 0.0002 \\
$\quad$ Drier & 113.9505 & 0.0332 & 0.93 & 0.0001 \\
\hline Snow Dynamics & & & & \\
$\quad$ Deeper Snowpack & 116.6501 & 0.0275 & 0.90 & 0.0003 \\
$\quad$ Shallower Snowpack & 114.8101 & 0.0287 & 0.92 & 0.0002 \\
\hline Fire Severity & & & & \\
$\quad$ Lower Severity (25\%) & 116.1617 & 0.0294 & 0.9 & 0.0003 \\
$\quad$ Higher Severity (75\%) & 103.884 & 0.0121 & 0.42 & 0.0833 \\
\hline Climate-disturbance Interactions & & & & \\
$\quad$ High Severity $\times$ Warming $\times$ Drier & 145.9954 & 0.0113 & 0.36 & 0.1160 \\
$\quad$ Low Severity $\times$ Warming $\times$ Wetter & 167.3116 & 0.0216 & 0.84 & 0.0014 \\
$\quad$ Snow Seasonality & 165.4936 & 0.0233 & 0.86 & 0.0010 \\
\hline
\end{tabular}

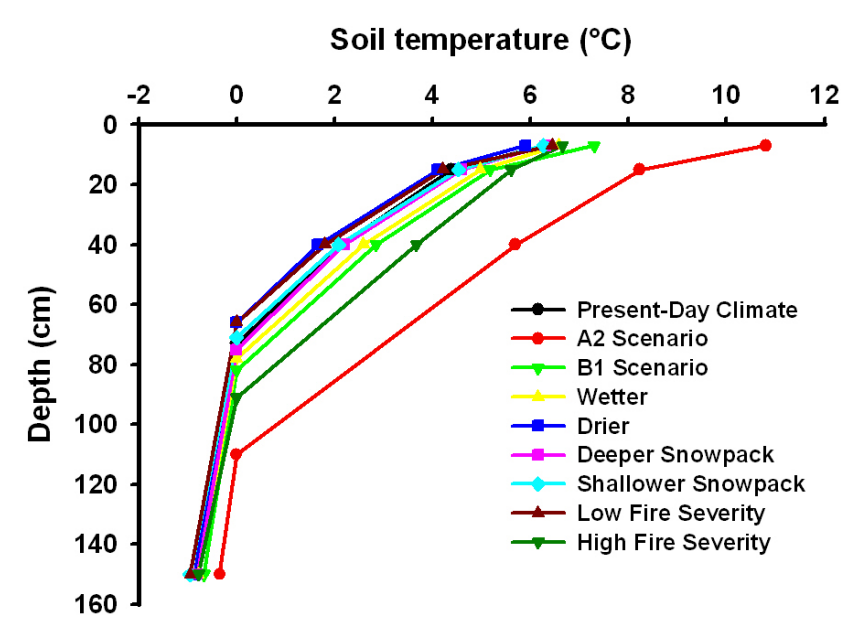

Fig. 5. Sensitivity of mean monthly temperature (MMT) in August to a suite of climatic and fire scenarios as modeled from GIPL. The depth of temperature data reflect positioning in shallow organic horizons $(<10 \mathrm{~cm})$, deep organic horizons $(15 \mathrm{~cm})$, unfrozen mineral soil in the active layer $(40 \mathrm{~cm})$, and permafrost $(1.5 \mathrm{~m})$. August MMT were used at each depth were used to drive the temperature sensitivity of organic matter decomposition (Eqs. 1 and 2) in the Fire-C model across this suite of climate and disturbance scenarios. published incubation studies from the boreal region (Clein and Schimel, 1995; Dioumaeva et al., 2003; Wickland and Neff, 2007). Our approach allowed us to differentiate temperature sensitivities across varying substrate types and ages (O’Donnell et al., 2011), which can strongly influence $Q_{10}$ values (Conant et al., 2008; Craine et al., 2010). The $Q_{10}$ values used for this study are generally higher than those reported in several recent studies (Bond-Lamberty et al., 2010; Mahecha et al., 2010). However, those studies calculated $Q_{10}$ values based on the relationship between soil respiration and air temperature, as opposed to the relationship between decomposition rates and soil temperature. The different approaches used to estimate $Q_{10}$ values (e.g. empirical vs. model-based, field vs. laboratory) have yielded varying results, fueling the ongoing debate regarding the temperature sensitivity of soil respiration (e.g. Kirschbaum, 2006). To reduce uncertainties regarding soil OC loss in response to future warming, more work is needed to resolve these differences and to further explore the underlying mechanisms driving temperature sensitivity (Davidson and Janssens, 2006).

\subsection{Effects of fire severity versus warming}

In a prior study, O'Donnell et al. (2011) illustrated the importance of fire severity on soil OC loss from deep soil horizons using the Fire-C model. Here, we show that the direct effects 


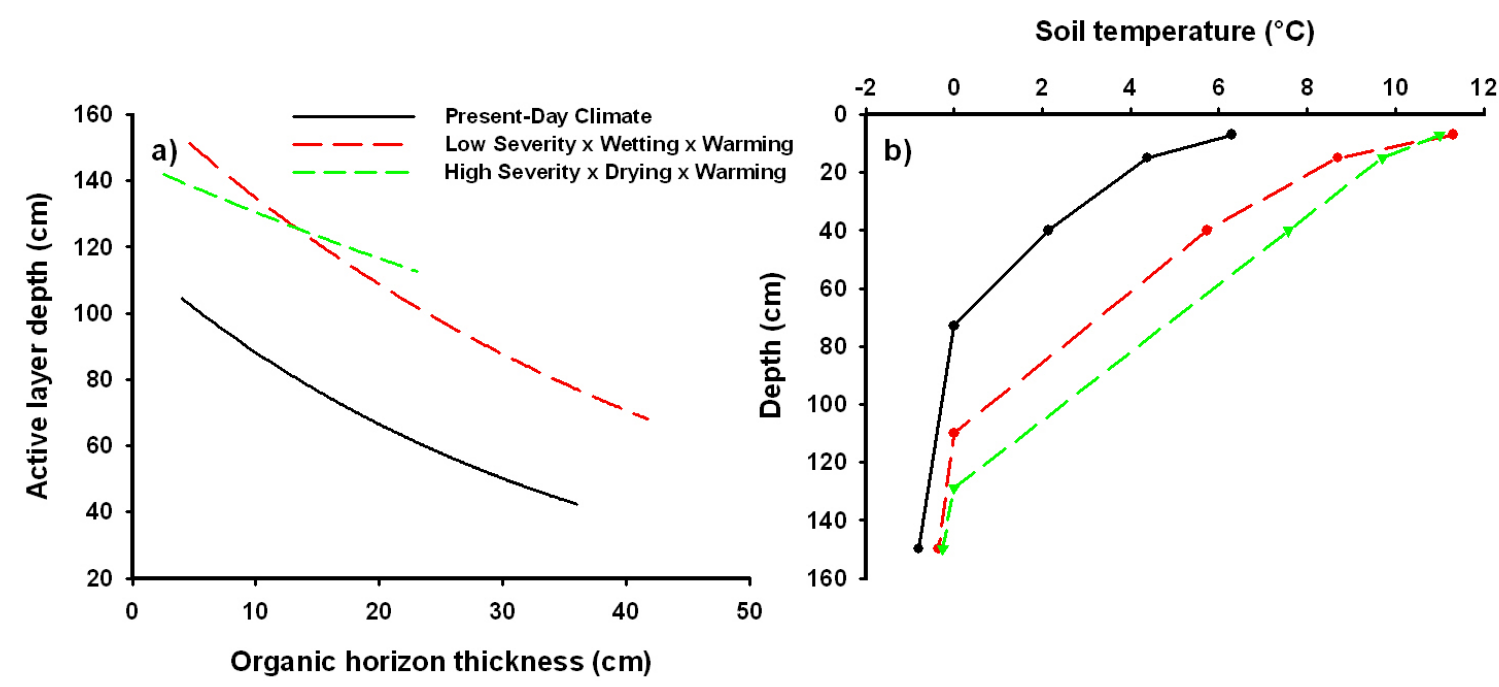

Fig. 6. Sensitivity of ALD (a) and mean monthly soil temperature in August (b) to multiple interacting factors. Using the GIPL model, we tested the effects of low fire severity, wetter soil conditions and warmer air temperatures (A2 scenario), high fire severity, drier soil conditions and warmer air temperatures, and changes in snow seasonality (following Euskirchen et al., 2009) associated with future warming (A2 scenario).

of increased fire severity on soil OC storage, while substantial, are generally smaller than the direct effects of warmer air temperatures. In reality, greater fire severity always results in warmer soils because of the insulating effect of organic layers on soil temperatures and active layer depth. For example, using the GIPL model, we showed that high severity fires result in increased ALD and soil temperatures following deep combustion of organic soil horizons (Fig. 4d), which enhanced OC losses from soil. These findings are consistent with other sensitivity analyses conducted in other black spruce ecosystems in the boreal region. In a recent analysis, Yi et al. (2011) illustrate that this post-fire soil warming and increases in ALD enhance soil decomposition and $\mathrm{N}$ mineralization in early succesional stands. Zhuang et al. (2002) illustrated that soil OC stocks in black spruce ecosystems are highly sensitive to fire severity, with large OC losses associated with high severity burns. Findings from Turetsky et al. (2011) indicate that increased fire severity in recent decades has accelerated regional $\mathrm{C}$ losses from Alaskan black spruce forests to the atmosphere. Therefore, as future warming will likely increase the size and severity of wildfires in the boreal region (Balshi et al., 2009; Flannigan et al., 2009), increases in OC loss from boreal soils will result.

Our sensitivity analyses also showed that soil OC stocks were also sensitive to changes in soil moisture. Under drier soil conditions (in the absence of fire), we observed relatively low OC losses from soil, a response driven by both physical and biological factors. Decreased soil moisture reduced the thermal conductivity of organic soil horizons, which is a dominant control on ALD in black spruce ecosystems (Bonan, 1989; Yi et al., 2009b; Jorgenson et al., 2010). By reducing ALD, a larger proportion of OC stocks in min- eral soil were reincorporated into the near-surface permafrost pool, where decomposition is essentially arrested. Together, cooler temperatures and drier conditions reduced decomposition rates, resulting in smaller OC losses relative to other scenarios. Under higher moisture conditions, we generally observed the opposite effect, with increased ALD, soil temperatures and decomposition.

Interactions between fire and soil drainage class will likely govern the extent of permafrost thaw and magnitude of soil OC losses following fire in the boreal region (Harden et al., 2001; Kane et al., 2007; Yi et al., 2009a). Surprisingly, we observed a similar magnitude of OC loss from both the high severity-dry treatment and the low-severity-wet treatment. This finding is likely due to a shift in the dominant mechanism driving soil temperature and OC dynamics between treatments. For instance, under the low severity-wet treatment, soil OC dynamics appear to be more sensitive to increased soil moisture and heat transfer than to the large reduction in organic horizon thickness than the decrease in soil moisture. In contrast, under the high severity-dry treatment, soil OC dynamics appear to be more sensitive to the large reduction in organic horizon thickness than to the decrease in soil moisture. Prior studies have documented the importance of organic horizon thickness and moisture on soil temperatures at the ground surface (Harden et al., 2006) and in nearsurface permafrost (Jorgenson et al., 2010). The response of OC and permafrost dynamics in black spruce ecosystems to future climate and fire regimes will likely depend on these feedbacks among organic horizon thickness, soil drainage, and soil temperature and permafrost dynamics (Johnstone et al., 2010). 


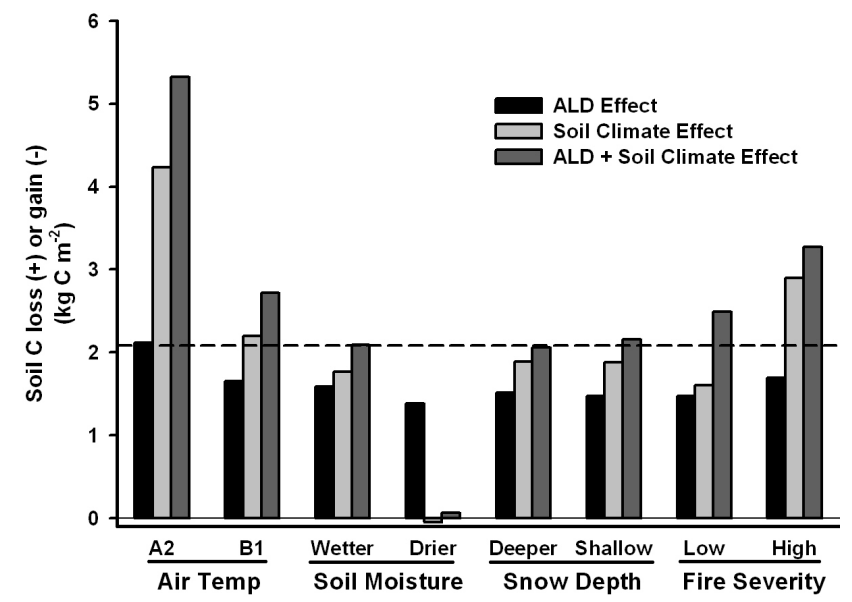

Fig. 7. The effect of single climate factors (air temperature, soil moisture, and snow depth) or fire severity on soil C storage. Soil C loss or gain was calculated as the difference in total soil $\mathrm{C}$ stocks in top $2 \mathrm{~m}$ of soil between model years 6500 and $7000 \mathrm{yr}$ (or approximately 3 fire cycles after step-change in climate/fire). To calculate the active layer depth (ALD) effect, we used only modified the relationship between ALD and organic horizon thickness (from Table 4) for each scenario in the Fire-C model. To calculate the soil climate effect, we modified decomposition constants within the Fire-C model to reflect future changes in soil temperature (Fig. 5) and/or soil moisture (Table 1). To calculate the ALD + soil climate effect, we modified both the ALD-OHT relationship and the decomposition constants within the Fire-C model. The dashed line represents total OC losses (ALD + soil climate) when present-day climate conditions (with no changes in snow, moisture or fire) were run for 3 fire cycles.

\subsection{Effects of snow dynamics on active layer depth, soil climate and soil carbon}

Increased duration of the snow-free season associated with future warming had a profound impact on ALD, soil climate and soil OC dynamics, although changes in snow depth alone had minimal effects. The longer snow-free season resulted in greater warming of soil, thawing of the near-surface permafrost, and soil OC losses relative to present-day conditions. However, our model simulations did not consider feedbacks associated with changes to snow seasonality, such as mid-summer drought (Welp et al., 2007) and increases in wildfire frequency (Kasischke and Turetsky, 2006). To more accurately assess the net effect of snow on soil OC dynamics in the boreal region, models are needed that consider the combined effects of snow, disturbance and hydrology (e.g. Yi et al., 2011).

Variation in snow dynamics across boreal succesional sequences has received little attention in the literature (see Euskirchen et al., 2009). Field measurements in this study show that winter soil temperatures were consistently warmer at the 2003 Burn relative to the Unburned Mature stand and the 1967 Burn (Supplement Fig. S1), despite similar snow

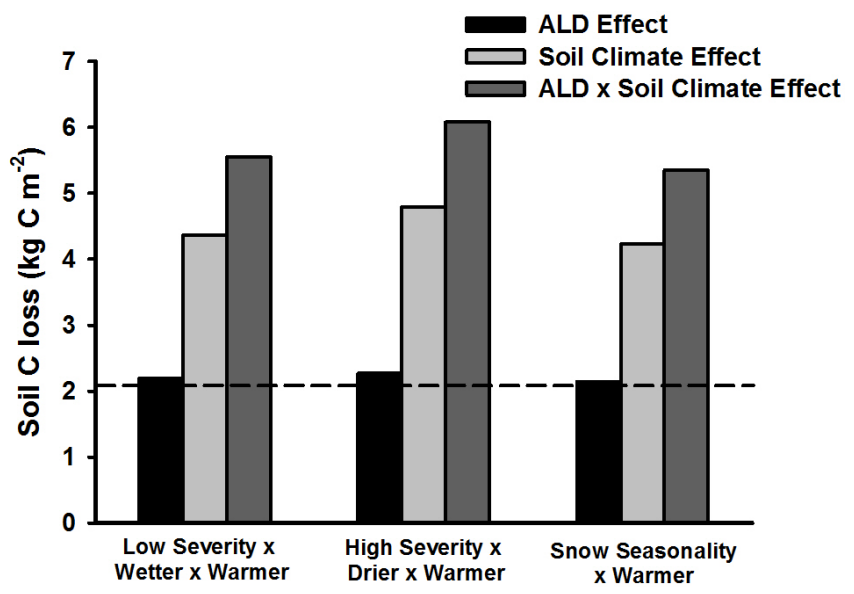

Fig. 8. The effects of combined climate/fire factors on soil $\mathrm{C}$ storage. The three scenarios reflect reduced fire severity associated with warmer and wetter soil conditions, higher fire severity associated with warmer and drier conditions, and longer snow-free season associated with warmer air temperatures. The ALD and soil climate parameterizations were derived from GIPL output as illustrated in Fig. 6. The dashed line represents total OC losses (ALD + soil climate) when present-day climate conditions (with no changes in snow, moisture or fire) were run for 3 fire cycles.

depths and seasonal dynamics across sites (Fig. 2a). These observations indicate that the magnitude of insulation is affected by the thermal properties of not only the snow, but also the underlying soil layers (Lachenbruch, 1959). This phenomenon is characterized by the parameter $\mu$ (Sasonova and Romanovsky, 2003), which quantifies the difference in thermal properties (heat capacity, thermal conductivity) between snow and the underlying soil layer. Higher $\mu$ values reflect increased insulation, and as a result, the thermal effect of snow should be more pronounced in recently burned stands (with thin organic horizons) than in mature stands (with thick organic horizons). These observations highlight the overriding importance of organic horizon thickness (Fig. 4), and thus stand age and fire severity, as important controls on soil thermal dynamics during winter and summer.

\subsection{Comparing the effects of active layer depth and soil climate on soil carbon loss}

The combined effect of ALD and soil climate on soil OC was generally less than the sum of each individual effect (ALD effect + soil climate effect; Figs. 7 and 8), suggesting that these factors are not distinct but have overlapping properties. While many studies in the boreal region have documented the soil climate effect on decomposition (Dioumaeva et al., 2003; Wickland and Neff, 2007; O'Donnell et al., 2009b; Karhu et al., 2010), the nature and importance of the ALD effect is less clear. We suggest that the ALD effect integrates three factors that govern soil OC cycling in the northern permafrost region. First, the ALD effect reflects the distribution of OC 
into unfrozen and frozen soil, which in turn, determines the size of the OC pool (C) and contributes to the decomposition rate $(-k C$; O'Donnell et al., 2011). Second, the ALD effect incorporates the impact of soil phase (i.e. frozen vs. unfrozen) on the temperature sensitivity of decomposition rates (see Rivkina et al., 2000; Mikan et al., 2002). Third, the ALD effect also reflects differences in the inherent decomposability of organic matter substrates in unfrozen $\left(k_{\text {active-layer }}\right)$ and frozen mineral soil ( $k_{\text {permafrost }}$; Waldrop et al., 2010). While the first property of the ALD effect is distinct from the soil climate effect, the other two properties overlap with the soil climate effect. Inter-annual variability in ALD likely drives small changes in the distribution OC between unfrozen and frozen pools, whereas periodic disturbances (e.g. wildfire, erosion) may result in large transfers of $\mathrm{OC}$ from permafrost to and from the active layer.

\section{Conclusions}

Recent field studies and modeling efforts have helped shape our understanding of soil OC dynamics in relation to wildfire and permafrost dynamics in the boreal region (Carrasco et al., 2006; Harden et al., 2006; Fan et al., 2008; Yi et al., 2009a, 2011; O'Donnell et al., 2011). Other studies have coupled thermal and biogeochemical models to investigate soil OC dynamics in northern ecosystems (Zhuang et al., 2001, 2002; Khvorostyanov et al., 2008; Yi et al., 2009b). However, our approach here is unique in that it incorporates field and laboratory parameterizations (O'Donnell et al., 2009a, 2011) into a modeling framework in which we explicitly evaluate fire-permafrost interactive effects on soil OC across a range of future climate conditions. Our findings illustrate that atmospheric warming and increased fire severity will likely drive larger OC losses from boreal soils than from changes in snow depth or soil moisture. Moreover, our findings explore the complex interactions among climate and disturbance factors, and in turn, draw attention to how these interactions function to increase soil OC loss. For instance, future increases in fire severity associated with a warmer and drier climate resulted in large OC losses through the deep combustion of organic soil horizons and subsequent warming and thawing of permafrost soils. Future decreases in fire severity associated with a warmer and wetter climate also resulted in similar OC losses, both by alleviating the moisture limitation of decomposition and by increasing heat conduction through wet organic soils. In each case, OC loss was governed by interannual changes in active layer depth, which determines the $\mathrm{OC}$ pool size in frozen and unfrozen mineral soil, and by the response of soil microbes to changing soil climate. Together, these findings highlight the need for modeling frameworks that consider the combined effects of fire, soil hydrology, permafrost and snow dynamics (e.g. Yi et al., 2011).

\section{Supplementary material related to this article is available online at: http://www.biogeosciences.net/8/1367/2011/ bg-8-1367-2011-supplement.pdf.}

Acknowledgements. Funding and support for J. O'Donnell was provided by the National Science Foundation grant EAR-0630249 and the Institute of Northern Engineering at the University of Alaska Fairbanks. We thank Eran Hood and two anonymous reviewers for providing valuable comments on an earlier version of this manuscript. The study was also supported by grants from the US Geological Survey to Harden and McGuire, and by the Bonanza Creek LTER (Long-Term Ecological Research) Program, funded jointly by NSF (grant DEB-0423442) and the USDA Forest Service (Pacific Northwest Research Station grant PNW01-JV11261952-231).

Edited by: U. Seibt

\section{References}

Balshi, M. S., McGuire, A. D., Duffy, P., Flannigan, M., Walsh, J., and Melillo, J.: Assessing the response of area burned to changing climate in western boreal North America using a Multivariate Adaptive Regression Splines (MARS) approach, Glob. Change Biol., 15, 578-600, 2009.

Bonan, G. B.: A computer model of the solar radiation, soil moisture, and soil thermal regimes in boreal forests, Ecol. Model., 45, 275-306, 1989.

Bond-Lamberty, B., Peckham, S. D., Ahl, D. E., and Gower, S. T.: Fire as the dominant driver of central Canadian boreal forest carbon balance, Nature, 450, 89-92, doi:10.1038/nature06272, 2007.

Bond-Lamberty, B. and Thomson, A.: Temperature-associated increases in the global soil respiration record, Nature, 464, 579582, doi:10.1038/nature08930, 2010.

Burn, C. R.: The response (1958-1997) of permafrost and nearsurface ground temperatures to forest fire, Takhini River valley, southern Yukon Territory, Can. J. Earth Sci., 35, 184-199, 1998.

Carrasco, J. J., Neff, J. C., and Harden, J. W.: Modeling physical and biogeochemical controls over carbon accumulation in a boreal forest soil, J. Geophys. Res-Biogeo., 111, G02004, doi:10.1029/2005JG000087, 2006.

Christensen, J. H., Hewitson, B., Busuioc, A., Chen, A., Gao, X., Held, I., Jones, R., Kolli, R. K., Kwon, W.-T., Laprise, R., Magaña, Rueda V., Mearns, L., Menéndez, C. G., Räisänen, J., Rinke, A., Sarr, A., and Whetton, P.: Regional Climate Projections, in: Climate Change 2007: The Physical Science Basis. Contribution of Working Group I to the Fourth Assessment Report of the Intergovernmental Panel on Climate Change, edited by: Solomon, S., Qin, D., Manning, M., Chen, Z., Marquis, M., Averyt, K. B., Tignor, M., and Miller, H. L., Cambridge University Press, Cambridge, United Kingdom and New York, NY, USA, 2007.

Clein, J. S. and Schimel, J. P.: Microbial activity of tundra and taiga soils at sub-zero temperatures, Soil Biol. Biochem., 27, 1231$1234,1995$. 
Conant, R. T., Drijber, R. A., Haddix, M. L., Parton, W. J., Eldor, P. A., Plante, A. F., Six, J., and Steinweg, J. M.: Sensitivity of organic matter decomposition to warming varies with quality, Glob. Change Biol., 14, 868-877, 2008.

Craine, J. M., Fierer, N., and McLauchlan, K. K.: Widespread coupling between the rate and temperature sensitivity of organic matter decay, Nat. Geosci., 3, 854-857, 2010.

Davidson, E. A. and Janssens, I. A.: Temperature sensitivity of soil carbon decomposition and feedbacks to climate change, Nature, 440, 165-173, 2006.

Dioumaeva, I., Trumbore, S., Schuur, E. A. G., Goulden, M. L., Litvak, M., and Hirsch, A. I.: Decomposition of peat from upland boreal forest: temperature dependence and sources of respired carbon, J. Geophys. Res.-Atmos., 108, 8222, doi:10.1029/2001JD000848, 2003.

Euskirchen, E. S., McGuire, A. D., Kicklighter, D. W., Zhuang, Q., Clein, J. S., Dargaville, R. G., Dye, D. G., Kimball, J. S., McDonald, K. C., Melillo, J. M., Romanovsky, V. E., and Smith, N. $\mathrm{V}$.: Importance of recent shifts in soil thermal dynamics on growing season length, productivity and carbon sequestration in terrestrial high-latitude ecosystems, Glob. Change Biol., 12, 731750, 2006

Euskirchen, E. S., McGuire, A. D., Rupp, T. S., Chapin III, F. S., and Walsh, J. E.: Projected changes in atmospheric heating due to changes in fire disturbance and the snow season in the western Arctic, 2003-2100, J. Geophys. Res.-Biogeo., 114, G04022, doi:10.1029/2009JG001095, 2009.

Fan, Z., Neff, J. C., Harden, J. W., and Wickland, K. P.: Boreal soil carbon dynamics under a changing climate: A model inversion approach, J. Geophys. Res.-Biogeo., 113, G04016, doi:10.1029/2008JG000723, 2008.

Flannigan, M., Stocks, B., Turetsky, M., and Wotton, M.: Impacts of climate change on fire activity and fire management in the circumboreal forest, Glob. Change Biol., 15, 549-560, 2009.

Friedlingstein, P., Cox, P., Betts, R., Bopp, L., von Bloh, W., Brovkin, V., Cadule, P., Doney, S., Eby, M., Fung, I., Bala, G., John, J., Joos, F., Kato, T., Kawamiya, M., Knorr, W., Lindsay, L., Matthews, H. D., Raddatz, T., Rayner, P., Reick, C., Roeckner, E., Schnitzler, K.-G., Schnur, R., Strassmann, K., Weaver, A. J., Yoshikawa, C., and Zeng, N.: Climate-carbon cycle feedback analysis: results from the $\mathrm{C}^{4} \mathrm{MIP}$ model intercomparison, J. Climate, 19, 3337-3353, 2006.

Frolking, S., Goulden, M. L., Wofsy, S. C., Fan, S.-M., Sutton, D. J., Munger, J. W., Bazzazz, A. M., Daube, B. C., Crill, P. M., Aber, J. D., Band, L. E., Wang, X., Savage, K., Moore, T., and Harris, R. C.: Modeling temporal variability in the carbon balance of a spruce/moss boreal forest, Glob. Change Biol., 2, 343-366, 1996.

Goodrich, L. E.: The influence of snow cover on the ground thermal regime, Can. Geotech. J., 19, 421-432, 1982.

Harden, J. W., O'Neill, K. P., Trumbore, S. E., Velhuis, H., and Stocks, B. J.: Moss and soil contributions to the annual net carbon flux of a maturing boreal forest, J. Geophys. Res.-Atmos., 102, 28805-28816, 1997.

Harden, J. W., Trumbore, S. E., Stocks, B. J., Hirsch, A., Gower, S. T., O'Neill, K. P., and Kasischke, E. S.: The role of fire in the boreal carbon budget, Glob. Change Biol., 6 (Suppl. 1), 174-184, 2000.

Harden, J. W., Meier, R., Silapaswan, C., Swanson, D. K., and
McGuire, A. D.: Soil drainage and its potential for influencing wildfires in Alaska, US Geological Survey Professional Paper, 1678, 139-144, 2001.

Harden, J. W., Manies, K. L., Turetsky, M. R., and Neff, J. C.: Effects of wildfire and permafrost on soil organic matter and soil climate in interior Alaska, Glob. Change Biol., 12, 2391-2402, 2006.

Heimann, M. and Reichstein, M.: Terrestrial ecosystem carbon dynamics and climate feedbacks, Nature, 451, 289-292, 2008.

Johnstone, J. F., Chapin III, F. S., Hollingsworth, T. N., Mack, M. C., Romanovsky, V., and Turetsky, M.: Fire, climate change, and forest resilience in interior Alaska, Can. J. Forest Res., 40, 13021312, 2010.

Jorgenson, M. T. and Osterkamp, T. E.: Response of boreal ecosystems to varying modes of permafrost degradation, Can. J. Forest Res., 35, 2100-2111, 2005.

Jorgenson, M. T., Racine, C. H., Walters, J. C., and Osterkamp, T. E.: Permafrost degradation and ecological changes associated with a warming climate in central Alaska, Climatic Change, 48, 551-579, 2001.

Jorgenson, M. T., Romanovsky, V., Harden, J., Shur, Y., O’Donnell, J., Schuur, E. A. G., Kanevskiy, M., and Marchenko, S.: Resilience and vulnerability of permafrost to climate change, Can. J. Forest Res., 40, 1219-1236, 2010.

Kane, E. S., Valentine, D. W., Schuur, E. A. G., and Dutta, K.: Soil carbon stabilization along climate and productivity gradients in black spruce forests of interior Alaska, Can. J. Forest Res., 35, 2118-2129, 2005.

Kane, E. S., Kasischke, E. S., Valentine, D. W., Turetsky, M. R., and McGuire, A. D.: Topographic influences on wildfire consumption of soil organic carbon in interior Alaska: implications for black carbon accumulation, J. Geophys Res.-Biogeo., 112, G03017, doi:10.1029/2007JG000458, 2007.

Karhu, K., Fritze, H., Hamalainen, K., Vanhala, P., Jungner, H., Oinonen, M., Sonninen, E., Tuomi, M., Spetz, P., Kitunen, V., and Liski, J.: Temperature sensitivity of soil carbon fractions in boreal forest soil, Ecology, 91, 370-376, 2010.

Kasischke, E. S. and Turetsky, M. R.: Recent changes in the fire regime across the North American boreal region - Spatial and temporal patterns of burning across Canada and Alaska, Geophys. Res. Lett., 33, L09703, doi:10.1029/2006GL025677, 2006.

Khvorostyanov, D. V., Krinner, G., Ciais, P., and Heimann, M.: Vulnerability of permafrost carbon to global warming. Part I: model description and role of heat generated by organic matter decomposition, Tellus B, 60, 250-264, 2008.

Kirschbaum, M. U. F.: Will changes in soil organic carbon act as a positive or negative feedback on global warming?, Biogeochemistry, 48, 21-51, 2000.

Kirschbaum, M. U. F.: The temperature dependence of organic matter decomposition - still a topic of debate, Soil Biol. Biochem., 38, 2510-2518, 2006.

Lachenbruch, A. H.: Periodic heat flow in a stratified medium with applications to permafrost problems, US Geological Survey Bulletin, 1083-A, 1959.

Lawrence, D. M., Slater, A. G., Romanovsky, V. E., and Nicolsky, D. J.: Sensitivity of a model projection of near-surface permafrost degradation to soil column depth and representation of soil organic matter, J. Geophys. Res-Earth, 113, F02011, doi:10.1029/2007JF000883, 2008. 
Lloyd, J. and Taylor, J. A.: On the temperature dependence of soil respiration, Funct. Ecol., 8, 315-323, 1994.

Limpens, J., Berendse, F., Blodau, C., Canadell, J. G., Freeman, C., Holden, J., Roulet, N., Rydin, H., and Schaepman-Strub, G.: Peatlands and the carbon cycle: from local processes to global implications - a synthesis, Biogeosciences, 5, 1475-1491, doi:10.5194/bg-5-1475-2008, 2008.

Mack, M. C., Schuur, E. A. G., Bret-Harte, M. S., Shaver, G. R., and Chapin III, F. S.: Ecosystem carbon storage in arctic tundra reduced by long-term nutrient fertilization, Nature, 431, 440443, 2004.

Mahecha, M. D., Reichstein, M., Carvalhais, N., Lasslop, G., Lange, H., Seneviratne, S. I., Vargas, R., Ammann, C., Altaf Arain, M., Cescatti, A., Janssens, I. A., Migliavacca, M., Montagnani, L., and Richardson, A. D.: Global convergence in the temperature sensitivity of respiration at ecosystem level, Science, 329, 838-840, 2010.

Manies, K. L., Harden, J. W., Bond-Lamberty, B. P., and O’Neill, K. P.: Woody debris along an upland chronosequence in boreal Manitoba and its impact on long-term carbon storage, Can. J. Forest Res., 35, 472-482, 2005.

Marchenko, S., Romanovsky, V., and Tipenko, G.: Numerical modeling of spatial permafrost dynamics in Alaska. Proceedings of Ninth International Conference on Permafrost, Ninth International Conference on Permafrost, Fairbanks, Alaska, USA, 29 June-3 July 2008, 1125-1130, 2008.

Mikan, C. J., Schimel, J. P., and Doyle, A. P.: Temperature controls of microbial respiration in arctic tundra soils above and below freezing, Soil Biol. Biochem., 34, 1785-1795, 2002.

Moody, J. A. and Martin, D. A.: Post-fire rainfall intensity-peak discharge relations for three mountainous watersheds in the western USA, Hydrol. Process., 15, 2981-2993, 2001.

Neff, J. C., Harden, J. W., and Gleixner, G.: Fire effects on soil organic matter content, composition, and nutrients in boreal interior Alaska, Can. J. Forest Res., 35, 2178-2187, 2005.

Nicolsky, D. J., Romanovsky, V. E., and Tipenko, G. S.: Using insitu temperature measurements to estimate saturated soil thermal properties by solving a sequence of optimization problems, The Cryosphere, 1, 41-58, doi:10.5194/tc-1-41-2007, 2007.

Nowinski, N. S., Taneva, L., Trumbore, S. E., and Welker, J. M.: Decomposition of old organic matter as a result of deeper active layers in a snow depth manipulation experiment, Oecologia, 163, 785-792, 2010.

O’Donnell, J. A., Romanovsky, V. E., Harden, J. W., and McGuire, A. D.: The effect of moisture content on the thermal conductivity of moss and organic soil horizons from black spruce ecosystems in interior Alaska, Soil Sci., 174, 646-651, 2009a.

O’Donnell, J. A., Turetsky, M. R., Harden, J. W., Manies, K. L., Pruett, L. E., Shetler, G., and Neff, J. C.: Interactive effects of fire, soil climate, and moss on $\mathrm{CO}_{2}$ fluxes in black spruce ecosystems of Interior Alaska, Ecosystems, 12, 57-72, $2009 \mathrm{~b}$.

O’Donnell, J. A., Harden, J. W., McGuire, A. D., Kanevskiy, M. Z., Jorgenson, M. T., and $\mathrm{Xu}, \mathrm{X}$. .: The effect of fire and permafrost interactions on soil carbon accumulation in an upland black spruce ecosystem of interior Alaska: implications for postthaw carbon loss, Glob. Change Biol., 17, 1461-1474, 2011.

O’Neill, K. P., Kasischke, E. S., and Richter, D. D.: Environmental controls on soil $\mathrm{CO} 2$ flux following fire in black spruce, white spruce, and aspen stands of interior Alaska, Can. J. Forest Res.,
32, 1525-1541, 2002.

Osterkamp, T. E. and Romanovsky, V. E.: Evidence for warming and thawing of discontinuous permafrost in Alaska, Permafrost Periglac., 10, 17-37, 1999.

Richter, D. D., O’Neill, K. P., and Kasischke, E. S.: Stimulation of soil respiration in burned black spruce (Picea mariana $\mathrm{L}$.) forest ecosystems: a hypothesis, in: Fire, climate change, and carbon cycling in the North American boreal forest, Ecological Studies 138, Springer, New York, New York, USA, 167-178, 2000.

Rivkina, E., Friedmann, E., McKay, C., and Gilichinsky, D.: Metabolic activity of permafrost bacteria below the freezing point, Appl. Environ. Microb., 66, 3230-3233, 2000.

Romanovsky, V. E. and Osterkamp, T. E.: Thawing of the active layer on the coastal plain of the Alaskan Arctic, Permafrost Periglac., 8, 1-22, 1997.

Romanovsky, V. E. and Osterkamp, T. E.: Effects of unfrozen water on heat and mass transport processes in the active layer and permafrost, Permafrost Periglac., 11, 219-239, 2000.

Romanovsky, V. E., Smith, S. L., and Christiansen, H. H.: Permafrost thermal state in the polar northern hemisphere during the International Polar Year 2007-2009: a Synthesis, Permafrost Periglac., 21, 106-116, 2010.

Sasanova, T. S. and Romanovsky, V. E.: A model for regionalscale estimation of temporal and spatial variability of active layer thickness and mean annual ground temperatures, Permafrost Periglac., 14, 125-139, 2003.

Schuur, E. A. G., Bockheim, J., Canadell, J. G., Euskirchen, E., Field, C. B., Goryachkin, S. V., Hagemann, S., Kuhry, P., Lafleur, P. M., Lee, H., Mazhitova, G., Nelson, F. E., Rinke, A., Romanovsky, V. E., Shiklomanov, N., Tarnocai, C., Venevsky, S., Vogel, J. G., and Zimov, S. A.: Vulnerability of permafrost carbon to climate change: implications for the global carbon cycle, Bioscience, 58, 701-714, 2008.

Schuur, E. A. G., Vogel, J. G., Crummer, K. G., Lee, H., Sickman, J. O., and Osterkamp, T. E.: The effect of permafrost thaw on old carbon release and net carbon exchange from tundra, Nature, 459, 556-559, 2009.

Stieglitz, M., Dery, S. J., Romanovsky, V. E., and Osterkamp, T. E.: The role of snow cover in the warming of arctic permafrost, Geophys. Res. Lett., 30, 1721, doi:10.1029/2003GL017337, 2003.

Tarnocai, C., Canadell, J. G., Schuur, E. A. G., Kuhry, P., Mazhitova, G., and Zimov, S.: Soil organic carbon pools in the northern circumpolar permafrost region, Global Biogeochem. Cy., 23, GB2023, doi:10.1029/2008GB003327, 2009.

Turetsky, M. R., Kane, E. S., Harden, J. W., Ottmar, R. D., Manies, K. L., Hoy, E., and Kasischke, E. S.: Recent acceleration of biomass burning and carbon losses in Alaskan forests and peatlands, Nat. Geosci., 4, 27-31, doi:10.1038/ngeo1027, 2011.

Viereck, L. A., Werdin-Pfisterer, N. R., Adams, P. C., and Yoshikawa, K.: Effect of wildfire and fireline construction on the annual depth of thaw in a black spruce permafrost forest in interior Alaska: A 36-year record of recovery, Proceedings of Ninth International Conference on Permafrost, Ninth International Conference on Permafrost, Fairbanks, Alaska, USA, 29 June-3 July 2008, 1125-1130, 2008.

Waldrop, M. P., Wickland, K. P., White III., R., Berhe, A. A., Harden, J. W., and Romanvosky, V. E.: Molecular investigations into a globally important carbon pool: permafrost-protected carbon in Alaskan soils, Glob. Change Biol., 16, 2543-2554, 2010. 
Welp, L. R., Randerson, J. T., and Liu, H. P.: The sensitivity of carbon fluxes to spring warming and summer drought depends on plant functional types in the boreal forest ecosystems, Agr. Forest Meteorol., 47, 172-185, 2007.

Wickland, K. P. and Neff, J. C.: Decomposition of soil organic matter from boreal black spruce forest: environmental and chemical controls, Biogeochemistry, 87, 29-47, 2007.

Yi, S., Manies, K., Harden, J., and McGuire, A. D.: Characteristics of organic soil in black spruce forests: Implications for the application of land surface and ecosystem models in cold regions, Geophys. Res. Lett., 36, L05501, doi:10.1029/2008GL037014, 2009a.

Yi, S., McGuire, A. D., Harden, J. W., Kasischke, E., Manies, K., Hinzman, L., Liljedahl, A., Randerson, J., Liu, H., Romanovsky, V., Marchenko, S., and Kim, Y.: Interactions between soil thermal and hydrological dynamics in the response of Alaska ecosystems to fire disturbance, J. Geophys. Res.-Biogeo., 114, G02015, doi:10.1029/2008JG000841, 2009b.

Yi, S., McGuire, A. D., Kasischke, E., Harden, J. W., Manies, K. L., Mack, M., and Turetsky, M. R.: A dynamic organic soil biogeochemical model for simulating the effects of wildfire on soil environmental conditions and carbon dynamics of black spruce forests, J. Geophys. Res.-Biogeo., 115, G04015, doi:10.1029/2010JG001302, 2011.
Yoshikawa, K., Bolton, W. R., Romanovsky, V. E., Fukuda, M., and Hinzman, L. D.: Impacts of wildfire on the permafrost in the boreal forests of interior Alaska, J. Geophys. Res.-Atmos., 108, 8148, doi:10.1029/2001JD000438, 2003.

Zhuang, Q., Romanovsky, V. E., and McGuire, A. D.: Incorporation of a permafrost model into a large-scale ecosystem model: Evaluation of temporal and spatial scaling issues in simulating soil thermal dynamics, J. Geophys. Res.-Atmos., 106, 33649-33670, 2001.

Zhuang, Q., McGuire, A. D., O’Neill, K. P., Harden, J. W., Romanovsky, V. E., and Yarie, J.: Modeling soil thermal and carbon dynamics of a fire chronosequence in interior Alaska, J. Geophys. Res.-Atmos., 108, 8147, doi:10.1029/2001JD001244, 2002.

Zimov, S. A., Schuur, E. A. G., and Chapin III, F. S.: Permafrost and the global carbon budget, Science, 312, 1612-1613, 2006. 